\title{
Multi-layer graphene oxide in human keratinocytes: Time-de- pendent cytotoxicity, proliferation, and gene expression
}

\author{
Beatriz Salesa ${ }^{1}$ and Ángel Serrano-Aroca ${ }^{1, *}$ \\ 1 Biomaterials and Bioengineering Lab, Centro de Investigación Traslacional San Alberto Magno, Universi- \\ dad Católica de Valencia San Vicente Mártir, c/Guillem de Castro 94, Valencia 46001, Spain; beatriz.sa- \\ lesa@ucv.es (B.S); angel.serrano@ucv.es (Á.S-A) \\ * Correspondence: angel.serrano@ucv.es
}

Citation: Lastname, F.; Lastname, F.; Last-name, F. Title. Coatings 2021, 11, x. https://doi.org/10.3390/xxxxx

\begin{abstract}
Few-layer graphene oxide (GO) has shown none or very weak cytotoxicity and anti-proliferative effects in a wide range of cell lines such as glyoma cells and human skin HaCaT cells, in concentrations up to $100 \mu \mathrm{g} / \mathrm{mL}$ However, multi-layer GO has been hardly explored in the biomedical field. Thus, multi-layer GO was examined here in human keratinocyte HaCaT cells treated with different concentrations ranging from 0.01 to $150 \mu \mathrm{g} / \mathrm{mL}$ during different periods of times $(3,12$ and 24 hours). The results of this study showed a time-concentration dependence with two non-cytotoxic concentrations $(0.01$ and $0.05 \mu \mathrm{g} / \mathrm{mL})$ and a median effective concentration value of 4.087 $\mu \mathrm{g} / \mathrm{mL}$ at 24 hours of GO exposure. Contrary to what has been reported for few-layer GO, cell proliferation of the HaCaT cells in contact with the multi-layer GO at $0.01 \mu \mathrm{g} / \mathrm{mL}$ showed identical proliferative activity compared to an epidermal growth factor (1.6-fold greater than the control group) after 96 hours. The effects of the multi-layer GO on the expression of 13 genes (SOD1, CAT, MMP1, TGFB1, GPX1, FN1, HAS2, LAMB1, LUM, CDH1, COL4A1, FBN and VCAN) at the non-cytotoxic concentrations of GO in the HaCaT cells were analyzed after 24 hours. Thus, the lowest noncytotoxic GO concentration was able to up-regulate the CAT, TGFB1, FN1 and CDH1 genes, which confirms the great potential of multi-layer GO in the biomedical field.
\end{abstract}

Keywords: graphene oxide; human keratinocytes; proliferation ; gene expression; cytotoxicity

\section{Introduction}

Graphene oxide (GO) is a carbon nanomaterial with great potential in the biomedical field due to its excellent physical, and unique biological properties such antimicrobial activity that render them very promising for a wide range of potential industrial applications [1,2]. In fact, GO has been proposed as next generation antiviral agent to treat the coronavirus disease 2019 (COVID-19)[3]. Thus, GO possess unique properties such as broad-spectrum antimicrobial properties capable of inactivating enveloped RNA viruses such as SARS-CoV-2 and bacteria such as Streptococcus pneumoniae, it presents low risk of inducing microbial resistance and it is able to induce tissue regeneration.

Multiple variants of this material have been synthesized and studied such as fewlayer nanosheets, multi-layer nanosheets, dots, nanocaps, flakes, nanoribbons or nanotubes, among many others [4,5]. Few-layer GO has shown no cytotoxicity in human A549 lung epithelial cells up to $48 \mathrm{~h}[6]$. Single layer GO showed lower toxicity in enter glioma cells than its reduced form ( reduced GO)[7]. Single layer GO showed low toxicity in NIH3T3 fibroblast cells[8] and single or two-layer GO in human lung fibroblast (HLF) cells assessed with methyl thiazolyl tetrazolium showed no cytotoxicity at $10 \mu \mathrm{g} / \mathrm{mL}$ after 24 hours[9]. Few-layer GO dose less than $20 \mu \mathrm{g} / \mathrm{mL}$ did not exhibit toxicity to human fibroblast cells either[10]. 
In the same research line, monolayer GO has shown less effect on cell viability than multi-GO in DC2.4 dendritic cells[11]. In that study, it was demonstrated that both monoGO and multi-GO significantly induced the generation of reactive oxygen species in the DC2.4 cells. However, another study performed with 1-layer GO and 4-layer GO showed similar cytotoxicity in human caucasian breast adenocarcinoma MCF7 cells after 48 hours exposure[12].

Regarding to human keratinocyte HaCaT cells, a previous study of few-layer GO showed low cytotoxicity and anti-proliferative capacity in this cell line [13]. However, as far as we know, the time-dependent cytotoxicity and proliferative activity of multi-layer GO (>10 layers) has never been studied in human keratinocyteHaCaT cells. Furthermore, the capacity of multi-layer GO to up-regulate genes associated with oxidative stress, extracellular matrix and synthesis of proteins related with the maintenance and repair of different tissues is studied here. Thus, the current study focuses on better understanding how this multi-layer nanomaterial affects not only cell toxicity, but also how it can be beneficial when it is used at low non-cytotoxic concentrations in terms of proliferative capacity and modifications in gene expression.

\section{Materials and Methods}

\subsection{Materials}

Graphene oxide nanosheets (GO, 15-20 sheets, 4-10\% edge-oxidized, Sigma-Aldrich, Switzerland) were used as received. This GO was previous characterized [14] and classified according to the number of graphene layers, average lateral size and carbon-to-oxygen $(\mathrm{C} / \mathrm{O})$ atomic ratio determined by Raman spectroscopy and high-resolution electron microscopy equipped with energy-disperse X-ray spectroscopy according to the GRAPHENE Flagship Project of the European Union for the unequivocal classification of these materials[15]. Thus, the results of this characterization showed a $\mathrm{G}$ peak intensity/2D peak intensity $\left(\mathrm{I}_{2} \mathrm{D} / \mathrm{I}_{\mathrm{G}}\right)$ ratio of 0.87 , which corresponds to a number of $\mathrm{GO}$ layers $>10$ in good agreement with the product information provided by the manufacturer (Sigma-Aldrich). The 2D GO nanosheets possess average lateral dimension of $153.8 \pm 57.2 \mathrm{~nm}$ and C/O ratio of 15.4 .

\subsection{Cytotoxicity Assay}

The cytotoxicity of different compounds was evaluated against HaCaT cell line, human keratinocytes, provided by La Fe Research Institute and Hospital, from 3-(4, 5-dimethylthiazol-2-yl)-2, 5-diphenyl tetrazolium (MTT) assay. First of all, 10000 cells per well resuspended in DMEM low glucose supplemented with $10 \%$ FBS, 5 \% peniciline-streptomicine, and $5 \%$ glutamine were seeded in 96 micro-well plates, and grown during 24 hours at $37{ }^{\circ} \mathrm{C}$ in a humidified atmosphere of $5 \% \mathrm{CO}_{2}$ in an incubator. The culture medium was subsequentially aspirated and replaced with $100 \mu \mathrm{L}$ of medium containing several concentrations of GO $(0.01,0.05,0.1,0.5,1,5,10,20,40,80$ and $150 \mu \mathrm{g} / \mathrm{mL})$. Stock solutions of nanomaterials were prepared in sterile DMEM low glucose without FBS supplemented with glutamine and antibiotics and were sonicated for 2 hours. Immediately, the solutions were prepared and dispensed to the cell culture. For each GO concentration, cells were incubated separately during different periods of time to evaluate the cytotoxicity at 3,12 and 24 hours. Six replicate samples were prepared in wells for each concentration. An untreated control was also run simultaneously at identical conditions. After incubation, medium was replaced with MTT reagent, incubated in the same conditions of the culture, and then formazan crystals were solubilized with DMSO. Cell viability was determined based on the absorbance at $550 \mathrm{~nm}$, using a micro plate reader Varioskan (ThermoScientific $^{\mathrm{TM}}$, Germany). In order to avoid false positives due to cell pigmentation with GO from concentration $80 \mu \mathrm{g} / \mathrm{mL}$ onwards, in parallel, the same experiment was carried out excluding the step of adding the MTT reagent. In this way, the background colour was subtracted from the final result. 


\subsection{Proliferation Assay}

In order to study the potential proliferation effect of GO in the HaCaT cell line, two non-toxic concentrations were chosen based on the cytotoxicity assay results. Cells were seeded in 96-well culture plate $\left(5 \cdot 10^{3}\right)$, and stock solution were prepared following the same protocol as indicated in the cytotoxicity assay with the exception of changing DMEM without FBS for DMEM with $0.5 \%$ FBS. In this case, cells were culture during 72 or 96 hours at $37^{\circ} \mathrm{C}$ in a humidified atmosphere of $5 \% \mathrm{CO} 2$ in the incubator. A positive control was included treating the $\mathrm{HaCaT}$ cells with epidermal growth factor (EGF) at $15 \mathrm{ng} / \mathrm{mL}$. Cell proliferation were measured using the MTT assay following the same procedure of the cytotoxicity assay.

\subsection{Gene expression}

Gene expression analysis was performed with the human keratinocyte cell line HaCaT seeded in 6-well culture plate at a density of $1.5 \cdot 10^{5}$ cells per well. Based on cytotoxicity assay results, two non-toxic concentrations at 24 hours were chosen to perform this assay. Stock solutions were prepared following the same protocol explained before for cytotoxicity and proliferation tests. After the cells were 24 hours with the compounds, the supernatant was aspirated and the cells were washed twice with PBS (1x) to remove any rest of the treatment. Immediately, extraction buffer was added to each well and plates were frozen in liquid nitrogen and preserved at $-80^{\circ} \mathrm{C}$ until RNA extraction was performed. Each condition was tested per triplicated. RNA was isolated using an RNA purification kit (Norgen, Canada) according to the manufacturer's protocol. Quality and concentrations of each sample were measured using a Nanodrop ${ }^{\mathrm{TM}}$ One (ThermoScientific ${ }^{\mathrm{TM}}$, Germany), and cDNA was synthetized using PrimeScript ${ }^{\mathrm{TM}}$ RT Reagent Kit (Perfect Real Time) (Takara Bio Inc.). To perform quantitative real-time PCR (qPCR), TB Green Premix Ex Taq (Takara Bio Inc. ) was used following the manufacturer's protocol, in a 384 QuantStudio 5 (ThermoScientific ${ }^{\mathrm{TM}}$, Germany). Data were analysed by the QuantStudioTM Design \& Analysis Software" software (ThermoFisher, Canada). The primers for amplification of fourteen target genes and reference gene ( $\beta$-actin/ACTB) were determined using Primer-Blast software (available on: http://www.ncbi.nlm.nih.gov/tools/primerblast). Data were normalized based on the expression of the reference gene. All primers used are listed in Table 1. 
Table 1. Details of gene-specific used in RT-qPCR assay.

\begin{tabular}{|c|c|c|c|}
\hline $\begin{array}{c}\text { Gene Symbol } \\
\text { (Access number) }\end{array}$ & Gene name & Oligo sequences & Function \\
\hline ACTB (NM_001101) & Actin beta & $\begin{array}{l}\text { 5'-CCATGCCCACCATCACGC-3' } \\
\text { 5'-CACAGAGCCTCGCCTTTG-3' }\end{array}$ & $\begin{array}{l}\text { Highly conserved protein that are involved } \\
\text { in cell motility, structure, and integrity }\end{array}$ \\
\hline CAT (NM_001752) & Catalase & $\begin{array}{l}\text { 5'-TGAATGAGGAACAGAGGAAACG-3' } \\
\text { 5'-AGATCCGGACTGCACAAAG-3' }\end{array}$ & $\begin{array}{l}\text { Encodes catalase, a key antioxidant enzyme } \\
\text { in the bodies defense against oxidative stress }\end{array}$ \\
\hline MMP1 (NM_001145938) & $\begin{array}{l}\text { Matrix metal- } \\
\text { lopeptidase } 1\end{array}$ & $\begin{array}{l}\text { 5'-GGACCATGCCATTGAGAAAG-3' } \\
\text { 5'-TCCTCCAGGTCCATCAAAAG-3' }\end{array}$ & $\begin{array}{l}\text { Involved in the breakdown of extracellular } \\
\text { matrix in normal physiological processes }\end{array}$ \\
\hline GPX1 (NM_000581) & $\begin{array}{l}\text { Glutathione } \\
\text { peroxidase } 1\end{array}$ & $\begin{array}{l}\text { 5'-TTTGGGCATCAGGAGAACGC-3' } \\
\text { 5'-ACCGTTCACCTCGCACTTC-3' }\end{array}$ & $\begin{array}{l}\text { Catalyse the reduction of organic hydroper- } \\
\text { oxides and hydrogen peroxide by glutathi- } \\
\text { one, and thereby protect cells against oxida- } \\
\text { tive damage }\end{array}$ \\
\hline COL4A1 (NM_000088) & $\begin{array}{l}\text { Collagen type I } \\
\text { alpha } 1\end{array}$ & $\begin{array}{l}\text { 5'-CAAGGGCGACAGAGGTTTGC-3' } \\
\text { 5'-AAAACTCACCAGGCTCCCCC-3' }\end{array}$ & $\begin{array}{l}\text { Abundant in bone, cornea, dermis, and ten- } \\
\text { don. Mutations in this gene are associated } \\
\text { with osteogenesis imperfect types I-IV }\end{array}$ \\
\hline TGFB1 (NM_000660) & $\begin{array}{l}\text { Transforming } \\
\text { growth factor } \\
\text { beta } 1\end{array}$ & $\begin{array}{l}\text { 5'-AGCTGTACATTGACTTCCGCA-3' } \\
\text { 5'-TGTCCAGGCTCCAAATGTAGG-3' }\end{array}$ & $\begin{array}{c}\text { Regulates cell proliferation, differentiation, } \\
\text { and growth }\end{array}$ \\
\hline HAS2 (NM_005328) & $\begin{array}{l}\text { Hyaluronan } \\
\text { synthase } 2\end{array}$ & $\begin{array}{l}\text { 5'-CCGAGAATGGCTGTACAATGC-3' } \\
\text { 5'-AGAGCTGGATTACTGTGGCAA-3' }\end{array}$ & $\begin{array}{l}\text { Serves a variety of functions, including space } \\
\text { filling, lubrication of joints, and provision of } \\
\text { a matrix through which cells can migrate }\end{array}$ \\
\hline LAMB1 (NM_002291) & $\begin{array}{l}\text { Laminin subu- } \\
\text { nit beta } 1\end{array}$ & $\begin{array}{l}\text { 5'-CAGGGTGTGCAGTCAGGGAA-3' } \\
\text { 5'-TGTGTCTGCGTTGAGGGTGT-3' }\end{array}$ & $\begin{array}{l}\text { Implicated in a wide variety of biological } \\
\text { processes including cell adhesion, differentia- } \\
\text { tion, migration, signalling, neurite outgrowth } \\
\text { and metastasis }\end{array}$ \\
\hline LUM (NM_002345) & Lumican & $\begin{array}{l}\text { 5'-ACTTGGGTAGCTTTCAGGGCA-3' } \\
\text { 5'-TTCCTGGCATTGATTGGTGGT-3' }\end{array}$ & $\begin{array}{l}\text { Is the major keratan sulfate proteoglycan of } \\
\text { the cornea but is also distributed in intersti- } \\
\text { tial collagenous matrices throughout the } \\
\text { body }\end{array}$ \\
\hline FN1 (NM_001306129) & Fibronectin 1 & $\begin{array}{l}\text { 5'-GGCCAGTCCTACAACCAGT-3' } \\
\text { 5'-CGGGAATCTTCTCTGTCAGC-3' }\end{array}$ & $\begin{array}{l}\text { Involved in cell adhesion and migration pro- } \\
\text { cesses including embryogenesis, wound heal- } \\
\text { ing, blood coagulation, host defense and me- } \\
\text { tastasis. }\end{array}$ \\
\hline VCAN (NM_001126336) & Versican & $\begin{array}{l}\text { 5'-CTGGTCTCCGCTGTATCCTG-3' } \\
\text { 5'-ATCGCTGCAAAATGAACCCG-3' }\end{array}$ & $\begin{array}{l}\text { Involved in cell adhesion, proliferation, mi- } \\
\text { gration, and angiogenesis and plays a central } \\
\text { role in tissue morphogenesis and mainte- } \\
\text { nance }\end{array}$ \\
\hline CDH1 (NM_001317184) & Cadherin 1 & $\begin{array}{l}\text { 5'-AACAGCACGTACACAGCCCT-3' } \\
\text { 5'-TCTGGTATGGGGGCGTTGTC-3' }\end{array}$ & $\begin{array}{l}\text { Loss of function of this gene is thought to } \\
\text { contribute to cancer progression by increas- } \\
\text { ing proliferation, invasion, and/or metastasis. }\end{array}$ \\
\hline FBN (NM_000138) & Fibrillin 1 & 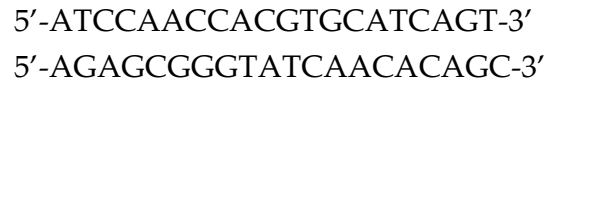 & $\begin{array}{l}\text { Extracellular matrix glycoprotein that serves } \\
\text { as a structural component of calcium-binding } \\
\text { microfibrils, providing force-bearing struc- } \\
\text { tural support in elastic and nonelastic con- } \\
\text { nective tissue throughout the body }\end{array}$ \\
\hline SOD1 (NM_000454) & $\begin{array}{l}\text { Superoxide } \\
\text { dismutase } 1\end{array}$ & $\begin{array}{l}\text { 5'-GGTGTGGCCGATGTGTCT-3' } \\
\text { 5'-TCCACCTTTGCCCAAGTCA-3' }\end{array}$ & $\begin{array}{l}\text { The protein encoded by this gene binds cop- } \\
\text { per and zinc ions and is one of two isozymes } \\
\text { responsible for destroying free superoxide } \\
\text { radicals in the body }\end{array}$ \\
\hline
\end{tabular}




\subsection{Statistical analysis}

The results obtained in this study were statistically analysed by ANOVA followed by multiple Tukey's post-hoc analysis. Median effective concentration (EC50) values were estimated using Probit analysis. Results were obtain using the GraphPad Prism 6 software at significance level of at least $p<0.05$.

\section{Results and discussion}

The time-dependent cytotoxicity, proliferation and gene expression results determined for multi-layer GO in human keratinocyte $\mathrm{HaCaT}$ cells is presented in the following subsections.

\subsection{Cytotoxicity Assay}

The cytotoxic effects of multi-layer GO were examined in HaCaT cells treated with different concentrations ranging from 0.01 to $150 \mu \mathrm{g} / \mathrm{mL}$ during different periods of times (3, 12 and 24 hours). At $3 \mathrm{~h}$ of treatment, only the highest concentration $(150 \mu \mathrm{g} / \mathrm{mL})$ was slightly toxic for the cell line (survival up to $75 \%$ ). Therefore, the EC 50 for this time was not possible to be determined due to the lack of toxicity above $50 \%$. However, the increase in the concentration and time exposure of the GO showed a negative correlation with the survival rate of the cells, which indicated a dose-dependent cytotoxicity (Figure 1).

(a)

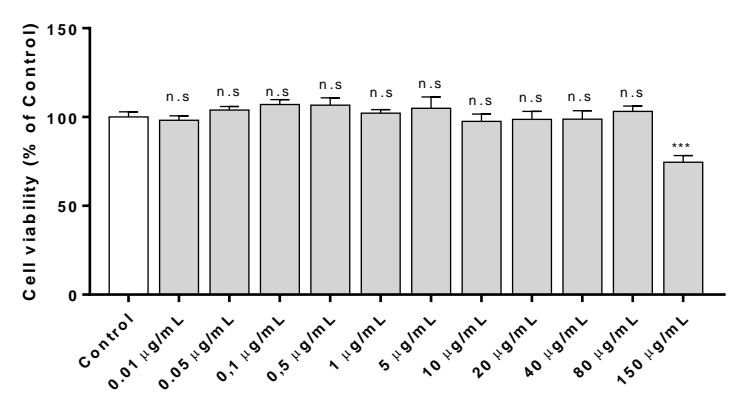

(b)

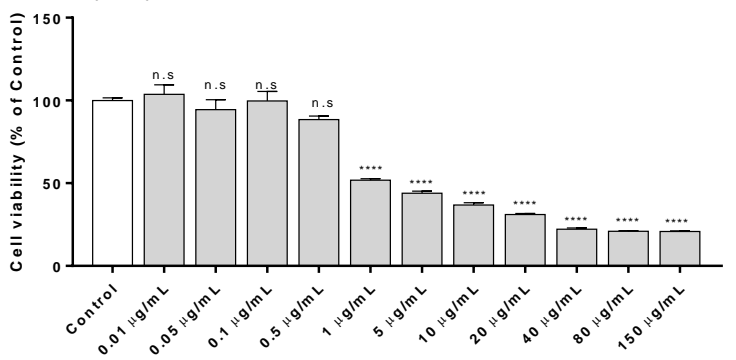

(c)

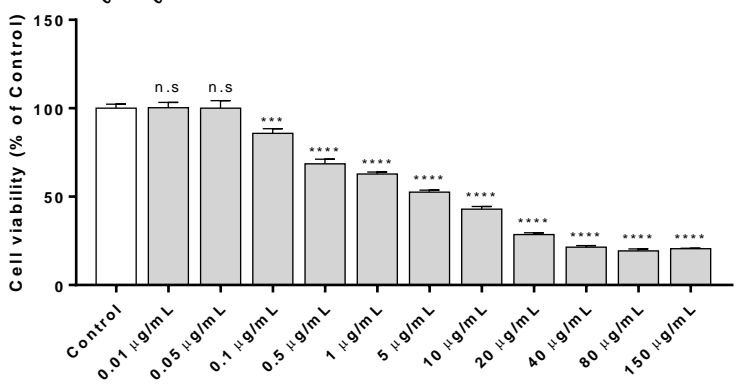

Figure 1. Cell viability in human keratinocyte HaCaT cells, after 3 (a), 12 (b) and 24 (c) hours of exposure to different concentrations of graphene oxide (GO) ranging from 0.01 to $150 \mu \mathrm{g} / \mathrm{mL}$. Cell viability was evaluated by the MTT assay. Results were represented as percentage of control group. Data are presented as the mean \pm standard error of six replicates. The ANOVA results of the different GO concentrations with respect to control are indicated in the plot. ${ }^{*} p>0.05 ;{ }^{* *} p>$ $0.01{ }^{* * *} p>0.001 ;$ n.s: not significant. 
Thus, the $\mathrm{EC}_{50}$ at 24 hours was lower than at 12 hours, indicating that the toxicity of GO increases with a prolonged treating time (Table 2).

Table 2. Mean effective concentration ( $\mathrm{EC}_{50}$ ) of $\mathrm{HaCaT}$ cells after treatment with graphene oxide (GO) at different exposure times. Mean $\mathrm{EC}_{50}$ and confidence limits $95 \%$ (CI) are shown as the mass-volume concentration, $\mu \mathrm{g} / \mathrm{mL}$. The goodness of fitness ( $\mathrm{R}$ square) is also indicated.

\begin{tabular}{cccc}
\hline GO exposure & EC $_{\mathbf{5 0}}(\boldsymbol{\mu g} / \mathbf{m L})$ & $\mathbf{9 5 \%}$ CI & R square \\
\hline $12 \mathrm{~h}$ & 5.615 & $4.302-7.237$ & 0.9045 \\
$24 \mathrm{~h}$ & 4.087 & $3.335-5.013$ & 0.9396 \\
\hline
\end{tabular}

Therefore, this type of multi-layer GO with more than 10 layers is more toxic than other few-layer GO studied previously in murine NIH-3T3 fibroblasts, U87 and U118 glioma cells, human lung fibroblasts cells, and even human skin HaCaT cells, up to 100 $\mu \mathrm{g} / \mathrm{ml}[7-10,13]$. These results are in good agreement with other studies such as that in which multi-GO showed more toxicity on cell viability than mono-GO in DC2.4 dendritic cells [11].

\subsection{Proliferation Assay}

Proliferation in human keratinocytes were stimulated by the exposure to GO at 72 and 96 hours (Figure 2).
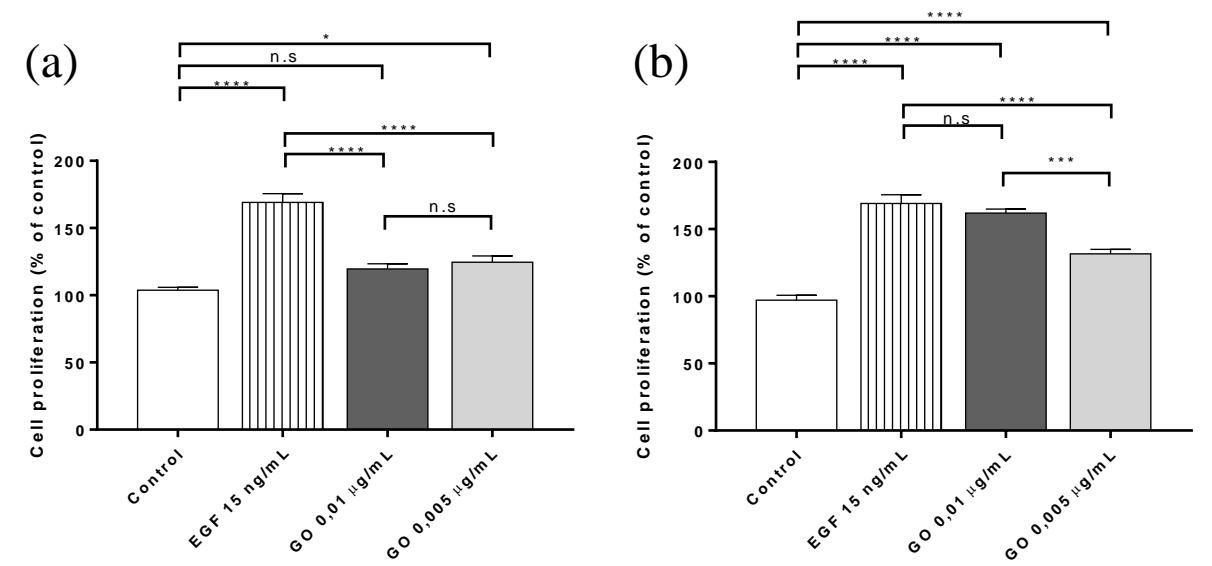

Figure 2. Proliferation in human keratinocytes stimulated by the exposure to GO at 72 (a) and at 96 (b) hours. Data are presented as the mean \pm standard error of the mean (SEM) of six replicates. The ANOVA results of the different graphene oxide (GO) concentrations and epidermal growth factor (EGF) with respect to control are indicated in the plot. ${ }^{*} p>0.05$; ${ }^{* *} p>0.01 ;{ }^{* * *} p>0.001 ;$ n.s: not significant.

72 hours of contact with the multi-layer GO was not enough time to induce a significant proliferative effect. Only a slight significant increase was observed at the highest non-cytotoxic GO concentration of $0.005 \mu \mathrm{g} / \mathrm{mL}$ with respect to the control group. However, the cell proliferation achieved at an exposure of 96 hours with the GO compound at $0.01 \mu \mathrm{g} / \mathrm{mL}$ was practically identical to that obtained with the epidermal growth factor. Thus, the cell proliferation at this low concentration of multi-layer GO was 1.6-fold greater than the control group after this longer time (96 hours). However, few-layer GO has shown anti-proliferative activity in glioma cells and human skin HaCaT cells [7,13]. Therefore, the proliferative effect achieved in these experiments could be attributed to the multilayer form of the GO (>10 layers) used in the present study. 


\subsection{Gene expression}

To determine the activation or inhibition of different metabolic routes (oxidative stress, extracellular matrix, synthesis of proteins related with the maintenance and repair of different tissues) due to the exposure of GO in human keratinocyte HaCaT cells, the expression levels of different genes (Table 1) involved in them were analysed. Thus, Figure 3 shows the effect of the multi-layer GO on the expression of 13 genes (SOD1, CAT, MMP1, TGFB1, GPX1, FN1, HAS2, LAMB1, LUM, CDH1, COL4A1, FBN and VCAN) at the noncytotoxic concentrations $(0.01$ and $0.05 \mu \mathrm{g} / \mathrm{mL})$ in HaCaT cells after 24 hours.

$0.01 \mu \mathrm{g} / \mathrm{m} \mathrm{L}$

$0.05 \mu \mathrm{g} / \mathrm{mL}$

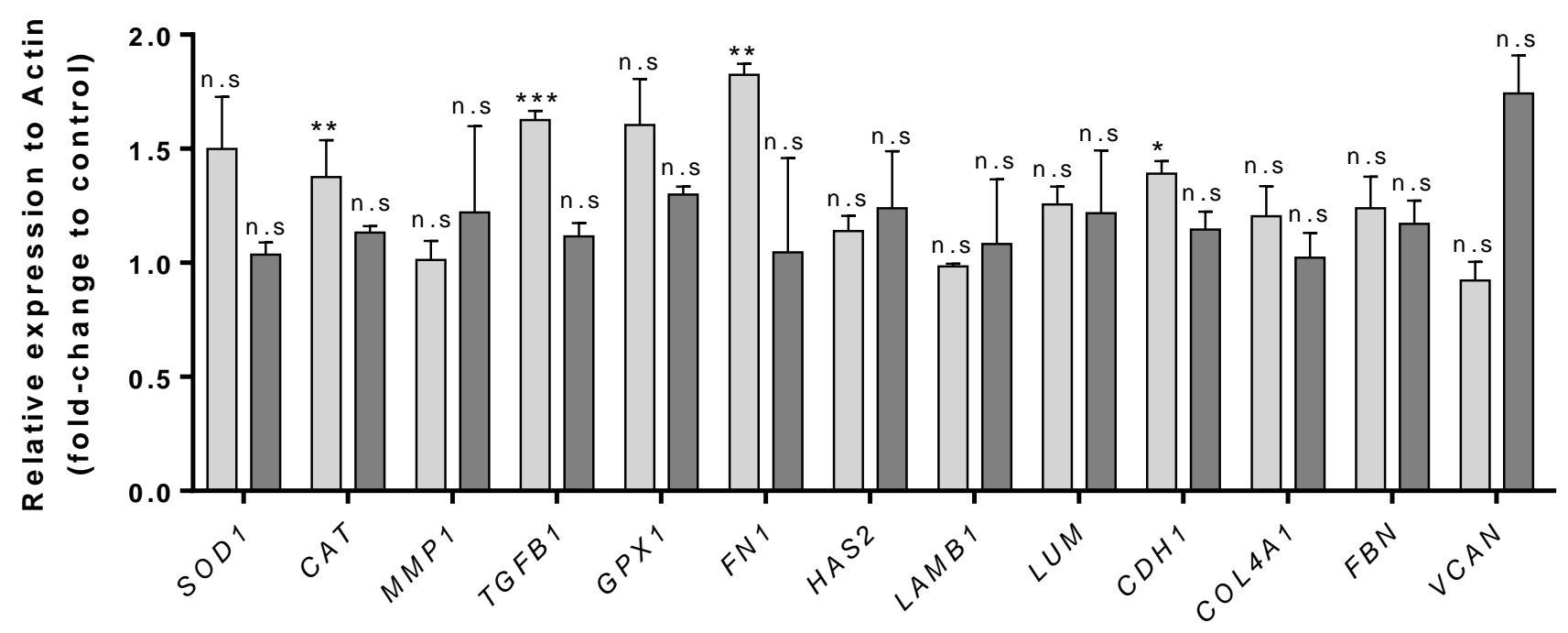

Figure 3. Effect of multi-layer GO on the expression of 13 genes (SOD1, CAT, MMP1, TGFB1, GPX1, FN1, HAS2, LAMB1, LUM, CDH1,COL4A1, FBN and VCAN) at the non-cytotoxic concentrations (0.01 and $0.05 \mu \mathrm{g} / \mathrm{mL})$ in the human keratinocyte HaCaT cell line after 24 hours. Data are presented as mean \pm SEM from three replicate measurements. Results were represented as fold-change of control and relative expression to ACTB. $\left({ }^{*} \mathrm{p}<0.05 ;{ }^{* *} \mathrm{p}<0.01\right.$; ${ }^{* * *} \mathrm{p}<0.001$, n.s: not significant)

The results of this study show that the exposure of GO for 24 hours did not produced any effect in human keratinocyte HaCaT cells at the highest concentration $(0.05 \mu \mathrm{g} / \mathrm{mL})$. This phenomenon could be attributed to the fact that this concentration is close to the cytotoxic level $(0.1 \mu \mathrm{g} / \mathrm{mL})$ determined in this study. However, the lowest non-cytotoxic concentration $(0.01 \mu \mathrm{g} / \mathrm{mL})$ induced an up-regulation of 4 genes (CAT, TGFB1, FN1 and $C D H 1)$ out of the 13 analysed genes. Thus, from the catalase $(C A T)$ and the glutathione per-oxidase 1 (GPX1) genes, which code for the synthesis of enzymes involved in the neutralization of $\mathrm{H}_{2} \mathrm{O}_{2}$, acting as importer antioxidants, only $C A T$ was up-regulated at the lowest concentration after 24 hours of exposure. Other researchers showed up-regulation of these two genes in HaCaT cells treated with caffeic acid or ferulic acid in a protective effect on cells from UVA radiation[16]. However, the required amount of these two compounds was much higher $(7.5-30 \mu \mathrm{g} / \mathrm{mL})$.

The low concentration exposure of GO in the HaCaT cells increased also the expression of TGFB1 that regulates cell proliferation, differentiation and growth $[17,18]$, and FN1 involved in cell adhesion and migration processes [19], respectively. These results are in good agreement with the results shown in Figure 2 and a recent study publish by our group[20]. In that study, the incorporation of multi-layer GO in a low percentage in the biopolymer poly(3-hydroxybutyrate-co-3-hydroxyvalerate) (PHBV) showed improved proliferative activity and enhanced cell adhesion of canine adipose-derived mesenchymal 
stem cells. This enhancements achieved with multi-layer GO were higher than those achieved with other carbon nanomaterial, carbon nanofibers[20].

Regarding to the genes involved in the synthesis of different proteins, only the expression of cadherin 1 (CDH1) was altered. The group of type I cadherins includes transmembrane glycoproteins that are vital in the morphogenesis and development of normal animal tissue[21]. HaCaT cell exposure to GO at $0.01 \mu \mathrm{g} / \mathrm{mL}$ induced an up-regulation of the gene involve in the synthesis of this glycoprotein.

The matrix metalloproteinases (MMPs) comprise a family of zinc-containing proteinases responsible of extracellular matrix proteins degradation produced by the skin cells including fibroblast and keratinocytes with clear links to malignancy[22]. A common way to induce the activation of matrix metallopeptidase 1 (MMP1) is through solar radiation. However, keratinocytes damaged by other pathways can activate this pathway on their own. Thus, Figure 3 shows that MMP1 were not activated by the GO exposure evidencing that the expression of this gene was not affected by the presence of the nanomaterial in $\mathrm{HaCaT}$ cells after 24 hours. Therefore, no negative effect on this gene can be attributed in that way. No alterations of the expression of the rest of genes analysed in this study were observed.

Therefore, in the biomedical field, multi-layer GO presents a time-concentration dependence and can be used with an optimal non-cytotoxic concentration of $0.01 \mu \mathrm{g} / \mathrm{mL}$, that is able to induce cell proliferation and up-regulate the CAT, TGFB1, FN1 and CDH1 genes.

\section{Conclusions}

Multi-layer GO has shown to be more toxic than what has been reported for fewlayer GO in human keratinocyte $\mathrm{HaCaT}$ cells. However, this multi-layer carbon nanomaterial showed proliferative activity similar to an epidermal growth factor (1.6-fold greater than the control group) after 96 hours, in contrast to the anti-proliferative effect of few-layer GO reported for the same cell line and glioma cells.

Exposure to a low non-cytotoxic concentrations of multi-layer GO $(0.01 \mu \mathrm{g} / \mathrm{mL})$ upregulates the $C A T$ gene that encodes the antioxidant catalase enzyme against oxidative stress, the TGFB1 gen that regulates cell proliferation, differentiation and growth, the FN1 gen that encodes cell adhesion and migration, and the $C D H 1$ gene involved in the synthesis of transmembrane glycoproteins, which confirms the biomedical potential of this hardly explored graphene oxide type.

Author Contributions: Conceptualization, methodology, validation, formal analysis, software, investigation, data curation, visualization, writing - original draft preparation: B.S. and Á.S.-A.; resources, supervision, project administration, writing - review and editing, funding acquisition: Á.S.-A. All authors have read and agreed to the published version of the manuscript.

Funding: This research was funded by the Fundación Universidad Católica de Valencia San Vicente Mártir, grant 2020-231-006UCV (awarded to Á.S-A).

Institutional Review Board Statement: Not applicable

Informed Consent Statement: Not applicable

Data Availability Statement: Data is contained within the article

Acknowledgments: The authors would like to express their gratitude to the Fundación Universidad Católica de Valencia San Vicente Mártir for their financial support.

Conflicts of Interest: The authors declare no conflict of interest. 


\section{References}

1. Martí, M.; Frígols, B.; Salesa, B.; Serrano-Aroca, Á. Calcium alginate/graphene oxide films: Reinforced composites able to prevent Staphylococcus aureus and methicillin-resistant Staphylococcus epidermidis infections with no cytotoxicity for human keratinocyte HaCaT cells. Eur. Polym. J. 2019, 110.

2. $\mathrm{Yu}, \mathrm{X}$.; Zhang, W.; Zhang, P.; Su, Z. Fabrication technologies and sensing applications of graphene-based composite films: Advances and challenges. Biosens. Bioelectron. 2017, 89, 72-84.

3. Serrano-Aroca, Á.; Takayama, K.; Tuñón-Molina, A.; Seyran, M.; Hassan, S.S.; Choudhury, P.P.; Uversky, V.N.; Lundstrom, K.; Adadi, P.; Palù, G.; et al. Carbon-based nanomaterials: Promising antiviral agents to combat COVID-19 in the microbial resistant era. Preprints 2021.

4. Ricci, R.; Leite, N.C.S.; Da-Silva, N.S.; Pacheco-Soares, C.; Canevari, R.A.; Marciano, F.R.; Webster, T.J.; Lobo, A.O. Graphene oxide nanoribbons as nanomaterial for bone regeneration: Effects on cytotoxicity, gene expression and bactericidal effect. Mater. Sci. Eng. C 2017, 78, 341-348.

5. Lu, P.; Zehtab Yazdi, A.; Han, X.X.; Al Husaini, K.; Haime, J.; Waye, N.; Chen, P. Mechanistic Insights into the Cytotoxicity of Graphene Oxide Derivatives in Mammalian Cells. Chem. Res. Toxicol. 2020, 33, 2247-2260.

6. Jasim, D.A.; Lozano, N.; Kostarelos, K. Synthesis of few-layered, high-purity graphene oxide sheets from different graphite sources for biology. 2D Mater. 2016, 3, 014006.

7. Jaworski, S.; Sawosz, E.; Kutwin, M.; Wierzbicki, M.; Hinzmann, M.; Grodzik, M.; Winnicka, A.; Lipińska, L.; Włodyga, K.; Chwalibog, A. In vitro and in vivo effects of graphene oxide and reduced graphene oxide on glioblastoma. Int. J. Nanomedicine 2015, 10, 1585-1596.

8. Ryoo, S.R.; Kim, Y.K.; Kim, M.H.; Min, D.H. Behaviors of NIH-3T3 fibroblasts on graphene/carbon nanotubes: Proliferation, focal adhesion, and gene transfection studies. ACS Nano 2010, 4, 6587-6598.

9. Wang, A.; Pu, K.; Dong, B.; Liu, Y.; Zhang, L.; Zhang, Z.; Duan, W.; Zhu, Y. Role of surface charge and oxidative stress in cytotoxicity and genotoxicity of graphene oxide towards human lung fibroblast cells. J. Appl. Toxicol. 2013, 33, 1156-1164.

10. Du, Y.; Ge, J.; Li, Y.; Ma, P.X.; Lei, B. Biomimetic elastomeric, conductive and biodegradable polycitrate-based nanocomposites for guiding myogenic differentiation and skeletal muscle regeneration. Biomaterials 2018, 157, 40-50.

11. Yang, Z.; Pan, Y.; Chen, T.; Li, L.; Zou, W.; Liu, D.; Xue, D.; Wang, X.; Lin, G. Cytotoxicity and Immune Dysfunction of Dendritic Cells Caused by Graphene Oxide. Front. Pharmacol. 2020, 11, 1206.

12. Peruzynska, M.; Cendrowski, K.; Barylak, M.; Tkacz, M.; Piotrowska, K.; Kurzawski, M.; Mijowska, E.; Drozdzik, M. Comparative in vitro study of single and four layer graphene oxide nanoflakes - Cytotoxicity and cellular uptake. Toxicol. Vitr. 2017, 41, 205-213.

13. Pelin, M.; Fusco, L.; León, V.; Martín, C.; Criado, A.; Sosa, S.; Vázquez, E.; Tubaro, A.; Prato, M. Differential cytotoxic effects of graphene and graphene oxide on skin keratinocytes. Sci. Rep. 2017, 7, 1-12.

14. Salesa, B.; Llorens-Gámez, M.; Serrano-Aroca, Á. Study of 1D and 2D carbon nanomaterial in alginate films. Nanomaterials 2020, 10, 206

15. Wick, P.; Louw-Gaume, A.E.; Kucki, M.; Krug, H.F.; Kostarelos, K.; Fadeel, B.; Dawson, K.A.; Salvati, A.; Vázquez, E.; Ballerini, L.; et al. Classification framework for graphene-based materials. Angew. Chemie - Int. Ed. 2014, 53, 7714-7718.

16. Pluemsamran, T.; Onkoksoong, T.; Panich, U. Caffeic acid and ferulic acid inhibit UVA-induced matrix metalloproteinase-1 through regulation of antioxidant defense system in keratinocyte HaCaT cells. In Proceedings of the Photochemistry and Photobiology; Photochem Photobiol, 2012; Vol. 88, pp. 961-968.

17. Duan, D.; Derynck, R. Transforming growth factor- $\beta$ (TGF- $\beta$ )-induced up-regulation of TGF- $\beta$ receptors at the cell surface amplifies the TGF- $\beta$ response. J. Biol. Chem. 2019, 294, 8490-8504.

18. Erlebacher, A.; Filvaroff, E.H.; Ye, J.Q.; Derynck, R. Osteoblastic responses to TGF- $\beta$ during bone remodeling. Mol. Biol. Cell 1998, 9, 1903-1918. 
19. Steffens, S.; Schrader, A.J.; Vetter, G.; Eggers, H.; Blasig, H.; Becker, J.; Kuczyk, M.A.; Serth, J. Fibronectin 1 protein expression in clear cell renal cell carcinoma. Oncol. Lett. 2012, 3, 787-790.

20. Rivera-Briso, A.L.; Aachmann, F.L.; Moreno-Manzano, V.; Serrano-Aroca, Á. Graphene oxide nanosheets versus carbon nanofibers: Enhancement of physical and biological properties of poly(3-hydroxybutyrate-co-3-hydroxyvalerate) films for biomedical applications. Int. J. Biol. Macromol. 2020, 143, 1000-1008.

21. West, J.J.; Harris, T.J.C. Cadherin Trafficking for Tissue Morphogenesis: Control and Consequences. Traffic 2016, 17, 12331243.

22. Nelson, A.R.; Fingleton, B.; Rothenberg, M.L.; Matrisian, L.M. Matrix metalloproteinases: Biologic activity and clinical implications. J. Clin. Oncol. 2000, 18, 1135-1149. 